\title{
KEREKERE AND INDIGENOUS SOCIAL ENTREPRENEURSHIP
}

\author{
Trisia Farrelly \& Alisi Talatoka Vudiniabola
}

\begin{abstract}
Since the colonial period, kerekere as an indigenous Fijian mode of exchange has been blamed for stunting the economic development of indigenous Fijians. It has often been reduced to 'begging' and it has been used in connection with terms such as 'corruption', and 'dependency'. This article strives for a more balanced and culturally complex account of kerekere. Business and vanua; modernity and tradition; capitalist and non-capitalist or market and moral economy are often imagined as dichotomous and irreconcilable by indigenous Fijians and others. This paper suggests that these are false dichotomies, and yet the way they are often imagined as dichotomous by indigenous Fijians has had a significant impact on their entrepreneurial discourse and practices. After surveying the relevant economic anthropology literature, the authors appeal for emic research which applies an integrated approach to contemporary economic activity in Fiji. We draw on ethnographic examples of community-based ecotourism within Taveuni's Boumā National Heritage Park and conclude that contemporary values and practices including kerekere may be strategically crafted and embedded into culturally meaningful expressions of indigenous social entrepreneurship.
\end{abstract}

\section{INTRODUCTION}

This paper explores the often contradictory, misunderstood, and impassioned responses to kerekere as indigenous Fijian 'customary borrowing' (Belshaw 1964: 121). Much of the paper focuses on the diverse and dynamic perspectives offered by economists, economic anthropologists, media, and Fijian nationals. The aim of this paper is to present the case for economic anthropology that provides nuanced and emic ethnographic accounts of particular economies. These accounts will progress work which counters erroneous traditional/modern and capitalist/non-capitalist discourses that persist in relation to Pacific economic activities such as kerekere. Farrelly's (2009) ethnographic work ex- 
plored community-based ecotourism in the Boumā National Heritage Park. Examples from this research provide context and support for the core argument of this paper. The authors conclude that anthropological engagements with indigenous social entrepreneurship case studies and literature may provide more complex analyses of contemporary Pacific economies as well as suggestions for culturally meaningful and empowering applications.

Contradictions in the value and existence of kerekere can be found the seminal texts of Oceanic economic anthropology. For example, kerekere receives little attention in Cyril Belshaw's (1964) Under the Ivi Tree: Society and Economic Growth in Rural Fiji, as Belshaw did not consider this practice important in the Sigatoka area at the time of writing (p.127), Capell (1968) and Nayacakalou (1978) describe kerekere as an integral part of vakavanua (traditional Fijian life) more broadly. More recently, this economic practice has been variously vilified, reified, and fervently defended for its 'tradition' and 'morality' in contemporary Fijian economic activity.

The authors conclude with a call for greater attention to indigenous social entrepreneurship in which capitalist and non-capitalist elements of economies are considered mutually constituted. Simultaneously, however, the authors recognise the tensions caused by the cultural construction of these false dichotomies and the authors will illustrate how these are negotiated in the development of indigenous enterprises. These enterprises require community support based on core cultural values and local configurations of cultural and social capital to survive and flourish.

KEREKERE AND THE VANUA

In early Fijian ethnographic literature, kerekere was often described as 'begging' (Capell, 1991; Thomas, 1993). Marshall Sahlins (1993), however, provides a more accurate definition in which kerekere is articulated as a way of requesting goods or services from a relative. The custom of requesting goods or services from kin is Pacific-wide. In Kiribati, this is known as bubuti; in Tonga, it is kolo; in Samoa it is called fua kavenga; and in Tuvalu it is known as fakamolemole (Couper, 2009).

According to Sahlins, kerekere can only be fully understood in relation to the whole kinship ethic and values of reciprocity shared by indigenous Fijians (i.e., he considered it a 'social fact'). The 'whole' he refers to here is the vanua. The vanua concept is a connective and relational indigenous Fijian worldview and 
complex set of rules to live by (Tuwere 2002:36). Kerekere, then, is a feature of 'life vakavanua' (the indigenous Fijian or vanua way):

[Vanua] does not mean only the land area one is identified with, and the vegetation, animal life and other objects on it, but it also includes the social and cultural system - the people, their traditions and customs, beliefs and values, and the various other institutions established for the sake of achieving harmony, solidarity and prosperity within a particular social context (Ravuvu, 1983:70).

Ravuvu may be criticised for evoking a mythical harmony in this definition. However, while the notion of a homogeneous harmonious community is a myth (Anderson, 1991; Guijt \& Shah, 1999; Hobsbawm, 1983; Wertheim, 1965), the vanua remains a crucial ideal for many indigenous Fijians. It prioritises the maintenance and strengthening of kinship ties and therefore social solidarity and social and economic security. In Fiji, sharing with relatives ensures that resources are efficiently used and that everyone is provided for in times of need. Kerekere continues to play a key role in this distribution of surplus. Hoarding (the accumulation of goods or profit), reported Narayan (1984), is neither practical nor necessary in Fiji because the basic requirements of indigenous Fijians are supplied through their kin-based networks (p.13). Despite the transformation of the concept vanua through engagement with the global market economy and colonialism, its essence remains ingrained in the psyches of the indigenous Fijian population (Batibasaga et al., 1999). Kerekere as a dynamic economic expression of the vanua is an example of a cultural activity that, under the right conditions, may adapt to straddle the past and the present. In so doing, it can contribute to the development of new culturally meaningful economic expressions.

Denying kerekere requests for goods or services may mean denial of the future requests of those who have denied and thus access to the kinship solidarity that affords a safety net to meet needs. In the same way, acts of kindness carry some expectation that they will be reciprocated in some way, sometime in the future (see Novaczek, Mitchell \& Veitayaki, 2005). For example, Rao (2004) describes kerekere as 'incur[ring] indebtedness...' (p.xix). However, if an individual or group kerekere to non-kin, this is considered madua (shameful). The authors are critical however, of the way that kerekere is too often reduced to a simple request and either denial or assent. In reality, there are number of phases and levels of kerekere and the outcome at each phase and level are highly dependent on context as illustrated in the diagram below: 


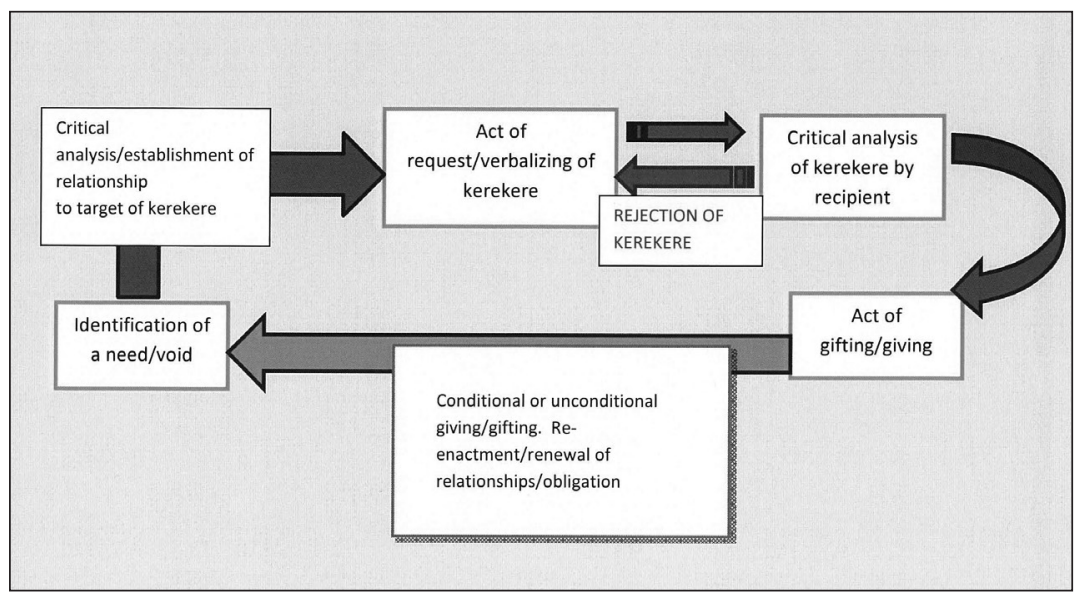

Figure 1. Kerekere diagram

Because kerekere is a key element of 'life vakavanua' (traditional Fijian life guided by the vanua concept), by extension, it is also key to what Boumā locals refer to as 'business vakavanua' (business conducted the vanua way). However, rather than romanticising kerekere (or vakavanua for that matter) as a reified, static, and authentically traditional practice (and therefore one that should be incorporated into all private, non-state enterprise), the authors acknowledge that business vakavanua is highly contested and fluid and often perceived, not only by Indo-Fijians and outsiders, but also many indigenous Fijians, as an unsound business model.

The aim of this paper is not to evaluate the success or failure of those businesses that have endeavoured to amalgamate kerekere into their businesses. What we do offer are some reasons why, for some indigenous Fijians, kerekere remains an essential element of all economic activity. Thus, we move beyond tradition/modernity and capitalist/non-capitalist analyses of economies to suggest that where kerekere is still considered a core element in Fijian life it may also be a vital element in contemporary rural business management.

The authors also acknowledge that kerekere has been reimagined and performed in ways that do not always reflect the core cultural values (of the vanua concept) currently shared by the majority of indigenous Fijians-no matter how 'traditional' they may imagine themselves. Williksen-Bakker (2002) and others have provided plenty of examples of businesses that have failed when they have tried to run them 'vakavanua' (the vanua way). However, success 
stories of Fijian businesses which apply indigenous Fijian principles of sharing, meeting traditional obligations for kin and the church are seldom given space in the public media and academic literature (e.g. see Williksen-Bakker, 2002: 73). Contemporary economic anthropology, however, provides a more sophisticated approach to understanding the culture of business in Fiji.

\section{ECONOMIC ANTHROPOLOGY}

Contemporary economic anthropology has contributed to the re-examination of what Marshall Sahlins refers to as 'zombie economic ideas' (2013). These are the persistent models which artificially separate economic from non-economic activities. Economic anthropology requires researchers to critically reflect on the ways in which we analyse economic activity. Consequently, now we recognise that much of what has been analysed is done so through Eurocentric capitalist assumptions and models. Through this lens, all economic activity as a social fact can be reduced to individual economic facts. Thus, we fail to recognise that all economic activity (including rational choice) is differently culturally determined.

In the 1970s, formalist anthropologists considered western economics to be based on the rational optimisation of resources and considered this economic model a universal (e.g. Raymond Firth [1929] and Harold K. Schneider [1974]). Conversely during the same period, substantivists, including Karl Polanyi (1944) and Marshall Sahlins (1972), posited that rational action was only relevant in Western economic contexts and that economies were diversely culturally constructed and enacted. Both substantivists and formalists perpetuated the assumption that societies were either capitalist (based on economic rationalism) or not (based on communal reciprocal exchange or 'gift economies'). At the time, neither entertained the notion that capitalist and non-capitalist elements could co-exist in one society at any given time.

Marcel Mauss's 'the spirit of the gift' in The Gift (1925) has often been misinterpreted thus reinforcing this dichotomous thinking. For example, in Chris Gregory's (1982) Gifts and Commodities, he argues:

Commodity exchange is an exchange of alienable objects between people who are in a state of reciprocal independence that establishes a quantitative relationship between the objects exchanged.... Gift exchange is an exchange of inalienable objects between people who are in a state of reciprocal dependence that establishes a qualitative relationship between the transactors (pp.100-1). 
In actuality, Mauss sought to dissolve the distinction between altruistic exchange (the gift) and selfish contracts (commodities) to reveal 'universal principles of mutual obligation and social integration' (Hann \& Hart, 2011:14). Economic anthropologists now accept that economic rationality and communal reciprocal exchange found in what is commonly described as 'gift economies' are not mutually exclusive (Wilk \& Cligett, 1996). Elements of these are found in all economies and are culturally determined and therefore, not universal. Plenty of ethnographic examples of this can be found in Browne and Milgram's (2009) Economics and Morality: Anthropological Approaches.

Tradition/modernity and capitalism/non-capitalism discourse arises in formalist/substantivist debates in economic anthropology. The debate between Marshall Sahlins (1993) and Nicholas Thomas (1992, 1992a, 1993) centred on whether or not kerekere was a pre-colonial institution, conflated the tradition/ modernity dichotomy with that of capitalism/non-capitalism. While Sahlins treated kerekere as a historically continuous mechanism for transforming material value to social value, Thomas (1989), Carrier (1992) and others asserted that kerekere did not exist pre-colonially. For Carrier, kerekere became a 'famous custom' (Sahlins 1962:145) only as a result of its objectification by Governor Gordon. In other words, kerekere was an 'invented tradition' or what Keesing (1982) called a 'political symbol' of Fijian custom and communality as a result of colonial politics. Kerekere is often discussed in relation to the Melanesian concept of kastom in such a way that both are objectified and treated as the following: neo-traditional, opposition concepts, ${ }^{1}$ and inauthentic. However, as Margaret Jolly writes in Spectres of Inauthenticity (1992), any notion of an 'authentic' tradition risks treating Pacific cultures as homogeneous, uncontested and unchanging. This paper similarly draws attention to diverse voices and how they perceive the contribution of kerekere to entrepreneurial enterprise. This includes various perceptions of local cultural identity and interpretations of 'modernity' and 'tradition' (see Brison, 2003).

The local voices in this paper compel us to move beyond modernity/tradition and capitalist-non-capitalist debates to locally contextualise economic activity as it is currently understood, valued, and practiced. Boumās economy is broader and more complex than one conceptualised as either capitalist or non-capitalist. Hart's 'human economy' (2010; Hart \& Hann, 2009) draws attention to this wider range of human needs and motivations than simply profit-making and economic growth. In Boumā, this wider range of human needs and motivations is driven by cultural connections between kin, lotu (church/ religion), and, land. This drive to maintain these connections is prioritised over financial profit. Ravuvu (1987) describes the traditional Fijian economy 
as a way of life emphasising 'the expending of material things for social and communal goals' (p.230) and states,

Fijians today are confronted with the most difficult task of adjustment of their lives: trying to maintain their uniquely Fijian world with its inherent beliefs and values against the influences of the market economy and its numerous ideologies of development (ibid).

This paper draws attention to this broader notion of economy while centring on the tensions, complexity, and ongoing negotiations undertaken by the Boumā people as they reflect on the value and meaning of economic practices in light of contemporary shifts in their socio-ecological landscape.

The following section exemplifies how the kinds of dichotomous thinking found in earlier tradition/modernity and formalist/substantivist thinking persists today. While the succeeding views are provided by a range of perspectives (including by indigenous Fijians), we posit that much of this criticism has been constructed through the perspective of western entrepreneurial dispositions, values, and typologies. Thus, we call for more emic locally-specific perspectives like the examples offered later in this paper if we are to grasp the nuanced local articulations of economic activities and values.

KEREKERE IN FIJI BUSINESS: THE BAD AND THE GOOD

Those who write about Fijians' potential to succeed in business are overwhelmingly pessimistic. It is perhaps kerekere that has most often been cited as the cause of small business and national economic failure in Fiji. That which is 'traditional' or 'cultural' has been publicly expressed as toxic to the success of indigenous Fijian business and kerekere is imagined as firmly placed on the 'traditional' side of the tradition/modernity dichotomy. Dennis Oliver's (1983) Trickling Up suggested that low levels of productivity in Fiji were attributed to the following: cultural lag; distribution of rewards; traditional work patterns and tenure; dependency mentality; inadequate infrastructure; low levels of education, skills and technology; powerlessness over export market prices; too hot/too wet and/or poor health. This application of an outdated modernisation theory is also found in Belshaw's (1964) seminal work Under the Ivi Tree. While Belshaw does not doubt that indigenous Fijians are 'enterprising', his work looks to capitalist-economic development to 'reduce stress' felt by indigenous Fijians. This includes greater access to credit and land reform. Belshaw lists the barriers to development as ancestral beliefs, close family attachments and a moderate fear of 'strangers'. 
A number of commentators note that indigenous Fijians are conspicuous in their poor levels of involvement in successful entrepreneurial endeavours (Fairburn, 1988:4; Ingram 1990). Their comparisons with the entrepreneurial success of Indo-Fijians have contributed to inter-racial tension and the call for affirmative action in order to balance out Indo-Fijian opportunity with that of indigenous Fijians (Ratuva 2002; Rao 2004; Williksen-Bakker 2002). During the Fiji coups $(1987,2000$, and 2006), it was repeatedly stated that Fijians needed to play a more significant part in business development in Fiji. The vanua with its emphasis on communal land tenure and values was presented in the media with increasing frequency as the point of comparison with which Fijians would debate the disparate economic successes between Indo-Fijians and indigenous Fijians. In Farrelly's (2009) research, indigenous Fijians referred to Indo-Fijian contributions to the economy with equal respect and disdain: on the one hand vilifying them as selfish and individualistic and for prioritising the accumulation of money over all else while at the same time complimenting and desiring their business prowess.

In 2004, Williksen-Bakker reported that some shops in urban centres had closed down as a result of demanding family members. Kerekere has recently also been associated with 'aid dependency' (Prasad, 2007), 'corruption' (Larmour, 2008; Prasad, 2007), 'bribes,' 'nepotism', and 'favouritism' (Larmour, 1997). While these are recent examples of negative interpretations of kerekere, its criticisms have a long history. Spate's Report (1959) records that 'kerekere puts a premium on laziness and is often a serious or even disastrous drain on those Fijians who are endeavouring to accumulate and to invest' (cited in Arbuckle, 1969:184). The Burns Commission Report (Burns, Watson, \& Peacock, 1960) mirrors this attitude: 'This is certainly one of the most severe handicaps under which the Fijian lives. An energetic and progressive man can be completely ruined by his predatory relatives' (para. 66). Under the Fijian Affairs Act (Cap 120, 1945 [Revised 2006]), kerekere involving the acquisition of more than 50 cents is still unlawful today but consistently ignored (20/1:25). More recently, the Asian Development Bank has detailed its position on kerekere as detrimental to entrepreneurial endeavours:

running a business runs contrary to the communal culture that emphasises sharing and obligation between family and clan members. With the traditional system of kerekere, some business people are finding it hard to reconcile the obligation to share with the need to protect and develop their business (2001:52). 
More writers are ambivalent or contradictory in their treatment of kerekere than those who are positive. For example, on the one hand, Duncan (2008) refers to kerekere as 'toxic' and speaks of the need to "quarantine" the indigenous entrepreneur from the cultural obligations of the village' (p.924). He thus 'encourages Pacific Islanders to move out of their communities to work in the market economy...returning home for holidays or when they retire' (p.928). On the other hand, he concludes by recommending the promotion of the 'development of the collectivist part of the economy if development assistance efforts are to be successful' (ibid).

Dorasammy Rao is equally contradictory. For Rao, kerekere is one collectivist practice which has 'profoundly hindered [indigenous Fijian] development' (Rao 2004:84). Rao's (2004) Culture and Entrepreneurship in Fijis Small Tourism Business Sector concludes that 'Fijian collectivism is rigid and that it has negatively influenced...entrepreneurial activities' (p.230) to the point that Indigenous Fijians may never 'catch up' to their Indo-Fijian counterparts and other ethnic groups who display a stronger set of entrepreneurial dispositions. He suggests that 'collective capitalism is politically problematic and that it has contributed to strengthening indigenous Fijian nationalism against IndoFijians. He also posits that collective capitalism will continue to create a lag in indigenous Fijian business development behind Indo-Fijians. Yet, in his conclusion, he calls for further investigations into collective capitalism due to its cultural relevance in indigenous Fijian contexts. Furthermore, when his research participants are asked, 'Can Fijian entrepreneurship develop in the context of prevailing cultural values?', his Indo-Fijian, Fijian, and Other respondents responded with a resounding 'yes' (94\%) (2004: 202).

Rao, like Duncan believes that successful indigenous Fijian entrepreneurs are generally those that have moved away from rural village communities and into urban centres. These entrepreneurs 'have not completely discarded their collectivist behaviours but have skilfully integrated their collectivist values with modern entrepreneurial needs. Modernity therefore has the prospect of gradually blending the Fijian culture with the needs of modern entrepreneurial needs' (Rao, 2004:204-205).

Many Fijians who run family businesses can easily identify what is genuinely a need from one that is not, and have policies in place to help make decisions about kerekere requests from their family members. For example, Ratu Aisea Waka Vosailagi (CEO of the highly successful indigenous Fijian family-owned Na Hina Trust) reveals what he considers the secret to Na Hina Trust's success despite negative indigenous business stereotypes: 
In most instances, we have the tendency to associate our traditional obligations and commitments together with the operational affairs of the company. This has always been a major tumbling blocks [sic] for most I Taukei [indigenous Fijian] businesses. However for $\mathrm{Na}$ Hina, in particular...the company had certain policies in place which strictly governs[sic] the peripheral [sic] of the company's operations. (Stolz, 2012, para 3).

Brison states, 'Individuals craft accounts of self and society, and modernity and tradition, that resolve the contradictions that arise in their own circumstances' (2003:356). However, when indigenous Fijians have reconfigured tradition including kerekere in order to suit their contemporary circumstances, they have been subjected to blanket criticisms by many social analysts as 'inauthentic' or 'disingenuous. While there are times when individuals and groups cross the line of what the majority of the population consider acceptable moral behaviour, blanket criticisms of any reconfiguration of cultural practices like kerekere only reinforce false and irreconcilable tradition/modernity and capitalist/noncapitalist dichotomies. For example, Durutalo (1997) observes that 'since the infusion of the capitalist system into the indigenous Fijian subsistence mode of production [what she refers to as a 'bastardised' form of the kerekere system] is used whereby anyone asks from anyone else due to poverty or financial difficulties' (p.19). In his analysis of the 'People' column of the Fiji Times, John Connell reported an emphasis on a 'new modern moral economy' which he said has nothing to do with tradition. Connell argues that kerekere has 'no role in business' within the construction of this 'new moral fable' (2007: 89). This is ironic considering the burgeoning literature on moral economy and the embeddedness of morality into economic activities whether considered capitalist or otherwise. The examples provided above represent tradition as somehow authentic, static, and timeless as criticised by Jolly (1992).

Some of the indigenous Fijian community have responded to criticisms of kerekere through a form of quiet, intentional deviance (Scott, 1985), by simply repetitively and cumulatively ignoring the abolition of kerekere under the Fijian Affairs Act. Others have not been so quiet. For example, in a Tears for Fiji article entitled 'Village Urged to Get Rid of Kerekere Culture' (2010), Strategic Framework for Change Coordinating Office representative, Kisoko Cagituevei, told a Provincial Council meeting that 'people in villages should focus on income generating sources and move away from subsistence agriculture in order to get rid of the kerekere culture. He also described kerekere as 'a stumbling block for development'. One Fiji citizen replied with this impassioned response: 
We, at TFF [Tears for Fiji] would like to know what data Cagituevei has that proves that our culture of "kerekere" is a stumbling block for our development. We cannot IGNORE our culture and think that ridding of such practices will magically make us all successful. Successful in what or whose terms? Cagituevei stressed that provincial councils should now preach the gospel of development to its people...[and] should align themselves with Government's development programs. Well this is more of the regime's propaganda than anything that is proactive and sustainable in the long term. Cagituevei should tell us then that him and his family has never ever gone to another to "kerekere" in their whole lifetime. That is totally unbelievable. Our customs and our culture and traditions make us who we are as a people. You cannot just come in and bulldoze your ideals and think it will work. Never! It takes time, changes in attitudes and minds, and most importantly one that the people will know will change for the better for them. Kerekere is here to stay, whether you like it or not (para 4-7).

Christy Harrington is one of a small number of social scientists who recognise the value of kerekere to sustaining vital social support systems for women in microenterprise in Fiji:

While putting a strain on individual assets, I would argue that the kerekere system boosts collective assets, contributing to the welfare of the members of the community who have less, and setting up future reciprocal obligations that ensure that those who give now will be entitled to ask for help should they need it later (2004:503).

The assumptions about kerekere shared by Rao and Duncan are representative of many who write about entrepreneurship in indigenous cultural contexts. Much of what is written adopts a notably ethnocentric approach to cultural analysis, deploying a western set of entrepreneurial dispositions or typologies (Woo, Cooper, \& Dunkelberg, 1991) which indigenous peoples must aspire to if they are to advance economically. Also, it is often implied that all indigenous peoples endeavour to achieve a universal 'success' and 'advancement' according to the same scripts as those who write from a non-indigenous perspective. Despite formalism's enduring legacy as evidenced in the examples provided in this section, the following section presents the emergence of more sophisticated ways of analysing economic activities. 
TOWARD AN INTEGRATED ECONOMIC MODEL

The formalist-substantivist debate was surpassed in the early 1980 os with the 'cultural turn'. At this time, economic anthropologists took a more holistic approach to economies and thus accounted for the full range of human organisation explored from a variety of perspectives. Contemporary economic anthropology argues that the processes involved in making a livelihood are variously culturally constructed. Therefore, rather than applying Eurocentric economic models universally, particular models of livelihoods and related economic concepts must be analysed through what Stephen Gudeman refers to as 'the local model' or 'the people's own economic constructions' (Gudeman, 1986:1). Some economic anthropologists argue that perhaps one of the most useful concepts to emerge from the formative-substantivist debate is 'embeddedness'. Embeddedness refers to the involvement of economic activities in other social processes as well as that of sociality and cultural value in economic activities and assumes that sociality drives and informs economic activity. This is also taken up by Cahn (2008) who states that entrepreneurship is dependent on non-economic institutions and activities including culture, social networks, politics, and religion' (p.1). Sahlins (2013), on the other hand, rejects the term 'embedded' because it implies that sociality and economic activity are separable. Gudeman (2009:18), on the other hand, argues that all economies are simultaneously embedded and disembedded, and that they contain two dialectically connected realms: the market (impersonal trade) and mutuality (community). This means that people in every society trade in both alienable and inalienable goods and services and these economic activities are constantly negotiated to mediate and reaffirm social relations (McCormack \& Barclay, 2013).

While formalists stressed economic rationality and self-interest (selfishness), substantivists stressed shared moral values, conceptions of justice, and conceptions of obligations held by all members of local society-elite and common people alike (moral economy). The concept moral economy was first coined by Russian economist Alexander Chayanov in the 1920s. It was further elaborated by English Historian E.P. Thomson (1971) and popularised by anthropologist, James Scott (1976). Scott suggested that villagers in South-East Asia were motivated by survival first and a subsistence ethic over profit. This was later criticised by Samuel Popkin (1979) for romanticising community and denying its peasant decision-makers rational individualism.

Clearly, a more complex and pluralistic description of 'moral economies' is required than the dichotomous one which situates capitalist against non-capitalist economies and by extension moral against selfish economies. Economic 
anthropologists have since argued that rationality is broader than 'self-interested utility maximisation' and that rational deliberation is framed by moral ideas, social commitments, and relationships of loyalty. In other words, 'selfinterested calculation and moral norms are present in all economies; what matters is their variable interplay' (Hann, 2011: 85). For example, sociologist, Andrew Sayer (2000), argues instead for economies that involve people working together in complex ways within an entangled web of social relations. He defines a moral economy as the study of 'how economic activities of all kinds are influenced and structured by moral dispositions and norms, and how in turn those norms may be compromised, overridden or reinforced by economic pressures' (p.2).

This definition reiterates that all economies - not merely pre- or non-capitalist ones are moral economies (Booth, 1994; Browne \& Milgram, 2009). Keith Hart's (2010) 'human economy' extends earlier anthropological work on the morality of economies and provides us with a more sophisticated analysis of economies than that provided by the substantivist-formalist debate. He defines human economy as one that attends to the thoughts, actions and lives of the humans that constitute economies rather than continuing to provide a depersonalised and de-moralised account of economic actions.

We present the following ethnographic example of Boumā as an indigenous business through a human economy lens. This provides a brief, messy, and complex insider snapshot of the Boumā National Heritage Park's communitybased ecotourism initiative as we attend to the thoughts, actions, and lives of those community members who struggle to creatively establish culturally meaningful businesses in Boumā.

\section{THE BOUMĀ NATIONAL HERITAGE PARK}

The ethnographic example provided here is based on Farrelly's nine months of participant-observation in three of the four villages that constitute the Boumā National Heritage Park (BNHP), Taveuni, Fiji. The four ecotourism initiatives included Tavoro Falls; Vidawa Forest Walk and Bird Watching; Lavena Coastal Walk and Backpackers Lodge; and the Waitabu Marine Reserve and Camping. While the fieldwork took place in 2004, her first visit to Boumā was in 2003 and research continued minimally after the fieldwork period until 2006 in the form of two short visits in 2005 and 2006 . She continued to follow media coverage on the Park, and limited email correspondence with a Peace Officer stationed in Boumā was maintained until 2006. While most of the research concentrated on Lavena Village where Farrelly, her husband, and one-year old 
son lived, she regularly visited the other villages. Her participants included those directly involved with ecotourism management and activities, as well as those who had either little interest or involvement with the ecotourism initiatives in the Park. Farrelly talked with people across clans, ages, genders, and community roles and attended community, Park management, and district meetings. In the nine months of fieldwork she had accumulated more than 150 hours of voice-recorded talanoa (informal interviews) with approximately 100 participants.

The BNHP is an indigenous Fijian example of community-based ecotourism. The park is communally-tenured land and the four villages and seven settlements who own and reside within the Park have established their own community-based ecotourism initiatives. According to Boumā elders, up until around the 1950s, their people were relatively self-sufficient. However, in their view, this self-sufficiency is now more tenuous. This is due to a greater reliance on tourism and cash cropping to relieve burgeoning financial pressures for education, and ceremonial obligations. All this is combined with ecological stress caused in part by over-population. Prior to the 1950s, money was seldom used for exchange in Boumā. This changed with the development policies of the 1950 and 1960 s to encourage economic growth (Yari, 2003) and the subsequent promotion of copra production.

Despite this shift toward a cash-based economy, in 2006, the Boumā people all grew their own food and fished to a greater or lesser extent. Few were solely reliant on cash-cropping or other commodity production. They continued many of the exchange arrangements integral to subsistence livelihoods in the past. The fickle nature of the tourism industry (for example, recent downturns due to political unrest and the global economic crisis), the devastating effect of cyclones (for example, Cyclone Tomas in 2010), and other environmental disasters including crop disease (for example, 'kava dieback') and widespread coral bleaching meant that its subsistence economy, supported by tight social networks, was crucial (Veitayaki, 2002).

While indigenous Fijians (including those in Boumā) used items such as whales' teeth (tabua), kava (piper methysticum/yaqona); artefacts such as pandanus textiles (ibe), pots (kuro), carvings, and food to obtain and return favours (Nayacakalou, 1978:102) in the past, not all of these are commonly exchanged today. Today, cash, reciprocal services, and store-bought items are the most common media of exchange in Boumā. This has put a greater strain on families and has occasioned an increased need to engage with the cash economy. While obligations to conduct collective village work (cakacaka vakoro) are 
part of traditional Fijian life, this may now be seen as taking labour away from the cash economy. At the same time, its erosion has led to the dilapidation of contemporary villages and the re-emergence of infectious diseases.

While many argue that Fijian village communities will only prosper by engaging in the cash economy, research elsewhere suggests that it is the cash economy that has led to such stressors. For example, Geschiere (2001) notes many of the negative implications of the introduction of a monied economy he observed in his fieldwork in southeast Cameroon in the 1990s. Similarly, Maria Bargh (2001) demonstrates how neoliberal forms of capitalism are detrimental to Pacific communities and observes that subsistence livelihoods are not seen as 'real production' to neoliberals. This is despite the fact that $70 \%$ of the region lives in subsistence-based rural villages and that the vast majority of production in the Pacific is for subsistence purposes' (p.261). Of particular relevance to the case of the BNHP, Jane Turnbull states that community conservation in the Pacific is designed to 'draw rural communities further into the cash economy' (2003:13).

In 1988, members of the largest Boumā village, Korovou, sought an alternative to selling their forests to a Korean company for toothpick production. They approached the Native Lands Trust Board (NLTB) to request assistance in establishing a forest park on their land. The BNHP was established on their indigenous tenured land in 1991. Each village has since established their own community-based ecotourism initiatives within the Park boundary. In the early days of the Park's establishment, the NLTB, Fiji Forestry, and Fiji Pine provided a top-down approach to development with little input from the local communities. The people of Boumā struggled to negotiate external values brought by business plans for the ecotourism initiatives: individualism, growth, competition, and democratic decision-making. Western concepts of community-based ecotourism management (СвЕM) had been applied with little attention to the complexities of the vanua. A lack of attention to historical events and cultural values contributed to a sense of anomie ${ }^{2}$ resulting in jealousy, mistrust, and internal conflict, and violence.

The more carefully an individual observes the laws of the vanua through community care and sharing, the more likely it is that they will experience sautu (Ravuvu, 1976:45). Nabobo-Baba (2006) describes sautu as 'good health and wealth' where good health is explained in terms of physical, emotional, psychological and spiritual well-being and wealth is 'an abundance of material resources...but more importantly... a wide and healthy network of relationships' (Nabobo-Baba, 2006:74). As such, the values of the vanua were determined 
by many locals to be antithetical to the values associated with capitalist entrepreneurship. For this reason, involvement in the market economy through ecotourism has made attaining sautu more complex than ever before. After almost twenty years of perseverance since the official opening of the BNHP, the community did not see their ecotourism initiatives as unsustainable. Instead, they remained hopeful that the project would bring them sautu. Through time, trial and error, they had been gradually creating their own meaningful and empowering forms of indigenous entrepreneurship (Dana \& Anderson, 2007; Hindle \& Landsdowne, 2007) based on the core values of the vanua. However, kerekere was a particularly difficult cultural element to negotiate in this process.

Some of my participants dreamed of an easy incorporation of kerekere into their new ecotourism business, while others set kerekere in direct opposition to business and felt it had no place outside the village activities (such as the ecotourism initiatives). Despite this, they continued to accept kerekere requests in their business activities. For example, the following individual directly involved in the Lavena Coastal Walk and Backpacker Lodge project opposed 'kerekereing' from the business even though he admitted that he had approached the project managers for money in the past:

That system is good only for the people in Lavena, not really for the business of tourism. It does not work because this 'ere'ere 'from family to family' business might put a big pressure on the person who is working on the books. They even 'ere'ere to me: 'Will you give some money for ...? I'll owe you the money'. If they want something, I just give it to them: 'Oh, you don't have to pay it back. That is my gift to help you'. I've got a small farm there up at the hill. We had a meeting with the park management to buy spray [Roundup]. We didn't have any money at that moment. I myself got some money from the park. But you can't do this in tourism. No. If you do, something is going to go wrong.

When the Vidawa Forest Hike was established seven years ago, the treasurer was regularly bombarded with requests for money from his kin within the community. He almost always complied until there were no funds left in the project kitty. As a result of this pressure from his family, he said that the project was doomed to failure. Later, in 2006, the Vidawa project had budgeted for these traditional requests in the running of the business but the treasurer was under strict instructions not to simply give money away. Rather, the project managers had arranged to respond to kerekere by requiring a reciprocal agreement in which the request must be repaid to the project in dalo (taro) tops. The 
dalo tops were planted and harvested for the project. In this way, his kin had their requests met while reinvesting in the project. In 2006, this appeared to be a successful compromise.

In Lavena, a former project manager said that up until around 2002, their management used to accept kerekere requests: 'For the last few years, when someone wanted some money, they just took it out of the business.' However, the manager decided that this was too damaging for the business and put a stop to it. This does not mean that kerekere requests were rejected outright. Like the Vidawa project, the manager tempered the kerekere arrangement so that the business remained financially sustainable. He did this by asking that the supplicant wait until the end of the year to ensure the project had enough funds to match the request. Despite the good intentions of the manager to ensure the business remained sustainable, he met with such opposition from his yavusa (sub-tribe/village) that he was made to step down. The community complained that he had acted autonomously and that he should have consulted with the community and with the rest of the board. In 2006, the Lavena project which was far more lucrative than that of the struggling Vidawa project had a built-in and unwritten allowance for genuine kerekere requests. Only some management and board members would admit to this as it was not transparent in the annual financial reports or to the district office auditor. Later, the Lavena ecotourism project chose to redefine kerekere as a 'loan' rather than a 'gift'. Therefore, when kerekere requests were made by kin, the recipient had to present evidence that they had the capital to repay the loan prior to the arrangement. If they had no capital, they were refused a loan. In this way, the Lavena ecotourism initiative has been able to marry business with vakavanua to meet the needs of both the business and the people. Since everyone is related in some way in each of the villages, the management and the business as a social entity (constituted by kin) may continue to fulfil social obligations.

Josefa, ${ }^{3}$ one of the past ecotourism project managers, said that two current project managers had the wrong attitude about running a business in Boumā and that was why they were constantly 'butting heads' with their boards and their village communities. He said that they had talked to the two managers about how they needed to make adjustments if they were going to succeed in leading their communities in the successful management of the projects. One of the pieces of advice that he offered was that kerekere requests must be honoured if the businesses were to be sustainable:

I told them the secret: 'If you won't change, problems will still be there. Everything is up to you. If the community said they need the 
money for this and you think to yourself, 'It's not right and it's not good. Even if you disagree, you should listen to them and do it. So if someone comes to you and says, 'Ere'ere, I need some money for...' whatever! You give it to them. We give an 'ere'ere request once a year and it will come back to us in so many other ways. And it works! I have talked to these managers and I have said to them, 'If you change, things will change for the better. But you have to change from the inside because even though you are a manager, you are not always right'. I mean, if I put in an idea to the committee, like if I think the project should donate $\$ 50$ for the church this month, but the committee disagrees, I leave it at that. I won't take it to the mataqali [clan] meeting. But if they agree, then I take it to the mataqali meeting. And if we take it to the mataqali meeting and they think that, no, we should give $\$ 100$ and we think $\$ 50$ - we go with the $\$ 100$. I can't go and tell them, 'No, we think we should only give $\$ 50$ ' because there are only seven of us in the committee and they are the whole mataqali, and we are working for them.

These examples reflect the communality that that some managers considered workable and core to business vakavanua while others saw this as an obstacle to modern business management. Most of my research participants felt that that without open, transparent, and frequent dialogue between the park managers and the rest of the community, community participation in their ecotourism enterprise in the fullest sense would be impossible. In this sense business practice should mirror the collectivist manner in which village decision-making took place. Therefore, ecotourism businesses could not be sustainable in Boumā if they did not adequately incorporate vanua principles including kerekere as understood and valued by most of the community at the time. Unfortunately, it appeared that open lines of communication between the park management and the community had broken down in three of the four ecotourism initiatives in Boumā at the time of research. Exacerbating this was an oft-cited concern about the perceived lack of chiefly leadership and the consequent reduction in respect for chiefs (Farrelly, 2011; 2013). Weak leadership meant there were frequent disagreements involving the relevance and applications of the current articulations of vanua (and therefore, kerekere) in the community-based ecotourism businesses.

INDIGENOUS SOCIAL ENTREPRENEURSHIP

This ethnographic case study has presented Boumās ongoing and collective efforts toward a culturally meaningful alternative to an economy based on purely 
capitalist values (Gibson-Graham, 1996, 2006). These efforts reflect immanent development (Cowen \& Shenton, 1996): constituted by 'what people are doing anyway'. This may be also understood as a 'life project' (Blaser, 2004).

Many examples of this fluid approach to moral economies can be found in the indigenous social entrepreneurship (ISE) literature. Anderson, Honig and Peredo (2006) define indigenous social entrepreneurship as embracing 'not only of economic prosperity, but also including collective cultural and social identity and well-being' (p.75). This advances the notion of a localised form of entrepreneurship which incorporates capitalist, non-capitalist, moral, and rational economic elements within a culturally determined business. In addition, economic activity is understood as metonymic of the whole of society. In other words, it is a social fact.

ISE may be distinguished from other forms of entrepreneurship by the fact that they are established and managed by indigenous peoples who share a common worldview and development goal. For those who have maintained links with their communities and their value systems, that common worldview is most likely to involve a social attachment to ancestral territories (Anderson, Honig \& Peredo, 2006:59). In Towards a Theory of Indigenous Entrepreneurship (2004), Peredo, Anderson, Galbraith, and Honig emphasise the notion of 'social embeddedness' in ISE. They define ISE as '[a] community acting corporately as both entrepreneur and enterprise in pursuit of the common good...to create and operate a new enterprise embedded in its existing social structure' (pp.15-6). This highlights a need to consider if any knowledge and values introduced by a new entrepreneurial endeavour is appropriate or meaningful in relation to the values, knowledge systems, social structures and protocols that already exist in a community. Maiava and King's (2007) 'indigenous development' based on Cowen and Shenton's (1996) 'immanent development' also helps to emphasise this point. Like non-indigenous development, it is 'motivated by that culture and directed by cultural criteria' (p. 85). Importantly, enterprise should be led and directed by local aims and objectives rather than those imagined for them by outsiders whose imaginations are limited by their own Eurocentric economic goals.

Despite the merits of ISE in terms of its more flexible and adaptive approach to indigenous economies, a more complex picture of 'community' than that implied in much of the ISE literature is needed. Wertheim (1965) and Guijt and Shah's (1999) 'myth of community'; Benedict Anderson's (1991) 'imagined communities'; and Hobsbawm's 'invented tradition' (1983) deny the homogeneity of social groups. It was certainly the case in Boumā that not all shared the 
same views about the value of kerekere in contemporary Fijian society nor if or how to incorporate it into their ecotourism business practices. Economic anthropology is well-placed to address this lacuna in ISE theory and practice.

\section{CONCLUSION}

Longitudinal participant-observation research coupled with acute attention to critical reflexivity and an emic perspective traditionally employed by economic anthropologists well-positions them to interpret what is often misread on the surface in other less comprehensive economic research conducted in indigenous Oceanic contexts. Ethnographic research can provide more sophisticated accounts of the ways individuals and communities negotiate externally introduced notions of entrepreneurship alongside pre-existing economic values and practices that are constitutive of the society as a whole (a social fact). Ethnographic research then is also well positioned to reveal the limits to individual and group agency in fruitfully negotiating new practices and values and making informed decisions. In Boumās case, the attempts to establish indigenous entrepreneurship were hampered more by a lack of respected community leadership ${ }^{4}$ than access to cash loans from banks and credit unions, communication services, or a relative fear of strangers (Belshaw, 1964). This is recognised by Ravuvu (2000) who suggests that most Fijian chiefs no longer have the power to influence their people. In the absence of strong chiefly leadership, like Karen Brison's (2007) research participants in Our Wealth is in Loving One Another, many of Farrelly's participants use their initiative to utilise 'traditional' and 'modern' economic categories strategically, and endeavoured to apply them simultaneously.

McClelland (1961) defines entrepreneurship as achieved rather than ascribed status; anti-traditionalism; and self-orientation rather than collectivism. In Boumā, these entrepreneurial values were deemed by most of Farrelly's participants as antithetical to 'tradition' or life lived vakavanua (the vanua way). Simultaneously however, local expressions of desire for life lived the vanua way were manifest in the innovative ways some were negotiating the amalgamation of the vanua (including kerekere) with non-indigenous entrepreneurial values introduced through community-based ecotourism development.

While Scott's (1976) work has been criticised for the dichotomisation of the moral and the capitalist economy, McCormack and Barclay (2013) emphasise that he does 'usefully draw attention to the frictions that may arise when capitalism is being negotiated. When the moral standard is threatened or ignored, resentment and resistance can be expected' (p.14). These frictions also arose 
in Boumā and while Farrelly's participants were innovative in negotiating the vanua with entrepreneurial values and practices, this did not occur without sacrifice and a crisis of identity. ${ }^{5}$ This crisis of self and the anxiety this attempt to reconcile tradition and modernity produces has been acknowledged by Brison (2003).

Since development consultants stepped back from the management of the BNHP projects in 2006, the people of Boumā had become increasingly conscious of the ways in which they creatively incorporate the vanua in the evaluation and management of their projects. This has been a step toward greater peace and prosperity (sautu) in Boumā. What we wish to emphasise here is the need to determine the motivations and goals for economic action. For the people of Boumā, much of the process and many of the goals are virtually indistinguishable as all of these must contribute to the strengthening of social bonds, cultural values, education, and well-being in the most holistic sense. All of these are encapsulated in sautu. The ongoing negotiations and innovations illustrated in the Boumā case contradict the persistent discourse that indigenous Fijian values are antithetical to those of Western entrepreneurship and that they are irreconcilable. The acknowledgement and encouragement of ISE may reduce the high failure rate of indigenous Fijian businesses based on meaningless or socially and culturally detrimental exogenous value systems. Contrary to the opinion of many writers, perhaps it is not kerekere itself, but its breakdown that is causing what some have referred to as a lag in economic development' and the transference of 'locally-based dependency and control to provincial, national and international institutions and forces' (Ravuvu, 1988:184).

For example, Batibasaga et al. (1999) state that the vanua could be used to develop 'an alternative set of values, based in the past but aware of the present, that can act as an effective counter to dominant ideologies of resource development and exploitation' (p.106). This approach to vanua is valuable in countering pervasive interpretations of kerekere as a tradition which is static, unself-conscious, resistant to innovation, and an impediment to economic and social progress. Indigenous communities can choose to either reject or engage with the global economy through their own culturally appropriate processes and timeframes. In such a way, they may work toward decolonising the development process in which entrepreneurship is only legitimate when conducted within a Eurocentric epistemological and ontological framework. This may mean the rejection, reification, re-imagination, or reorientation of kerekere. 
NOTES

1 Nicholas Thomas (1989:76) argues that 'modern Pacific cultures and practices are organized oppositionally'. In other words, culture is constructed in opposition to something; for example, Christianity and colonialism in the case of kastom.

2 Emile Durkheim's use of French philosopher, Jean-Marie Guyau's term 'anomie' in Le Suicide (1897) describes anomie as a disintegration of standards or values, or 'normlessness', and a feeling of alienation or purposelessness. He writes that anomie normally occurs in societies undergoing dramatic economic change. The change that occurs is at odds with what is actually achievable in everyday mundane life.

3 Pseudonyms have been used throughout this article.

4 See this in detail in Farrelly, 2011.

5 This was evidenced in a threat to burn down Lavena Lodge, and the murder of a Vidawa leader (see Farrelly, 2009).

\section{REFERENCES}

Anderson, B. (ed.) 1991 Imagined Communities. London: Verso.

Anderson, R., Honig, B. and Peredo, A. 2006 'Communities in the new economy: where social entrepreneurship and Indigenous entrepreneurship meet', in C. Steyaertt and D. Hjorth (eds) Entrepreneurship as Social Change. Cheltenham: Edward Elgar:56-78.

Arbuckle, G. 1969 Economical and social development in the Fiji Islands through credit union. Journal de la Société des Océanistes, 25:169-88.

Asian Development Bank 2001 Financial Sector Development in the Pacific Developing Member Countries. Asian Development Bank, Manila.

Bargh, M. 2001 'Romance and resistance in the Pacific: neoliberalism and indigenous resistance in the Pacific', Revue Juridique Polynésienne 1:118.

Batibasaga, K., Overton, J., \& Horsley, P. 1999 'Vanua: land, people, and culture in Fiji', in J. Overton \& R. Scheyens (eds), Strategies for Sustainable Develop- 
ment: Experiences from the Pacific. London \& New York: Zed Books:10o-8.

Belshaw, C.S. 1964 Under the Ivi Tree: Society and Growth in Rural Fiji. London: Routledge \& Kegal Paul.

Blaser, M. 2004 'Life projects: indigenous people's agency and development', in M. Blaser, H. A. Feit \& G. McRae (eds), In the Way of Development: Indigenous Peoples, Life Projects, and Globalization. London \& New York: Zed:26-44.

Booth, W.J. 1994 'On the idea of the moral economy', The American Political Science Review, 88(3): 653-67.

Brison, K.J. 2003. 'Imagining Modernity in Rural Fiji'. Ethnology, 42(4):335-348.

Brison, K.J. 2007 Our Wealth is in Loving One Another, Plymouth, UK: Lexington Books.

Browne, K.E. and Milgram, B.L (eds) 2009 Economics and Morality: Anthropological Approaches (Society for Economic Anthropology Monograph Series). Plymouth: Altamira Press.

Burns, A., Watson, T. and Peacock, A. 1960 Report of the Commission of Enquiry into the Natural Resources and Population Trends of the Colony of Fiji. Fiji Legislative Council Paper CP, 1, 1960, Suva.

Cahn, M. 2008 Indigenous entrepreneurship, culture and micro-enterprise in the Pacific Islands: case studies from Samoa. Entrepreneurship \& Regional Development: An International Journal, 20(1):1-18.

Capell, A. (ed) 1968 A New Fijian Dictionary (3rd edn), Portsmouth, England: Eyre \& Spottiswoode.

Carrier, J. G. (ed) 1992 History and Tradition in Melanesian Anthropology, Berkeley University of California Press.

Chayanov, A. V. 1966 [1925] The Theory of Peasant Economy, Madison, Illinois: University of Illinois Press.

Connell, J. 2007 'The Fiji Times and the good citizen: constructing modernity and nationhood in Fiji. The Contemporary Pacific, 9(1): 85-109. 
Couper, A. 2009 Sailors and Traders: A Maritime History of the Pacific Peoples, Honolulu: University of Hawai' i Press.

Cowen, M.P. and Shenton, R.W. (eds) 1996 Doctrines of Development. London \& New York: Routledge.

Dana, L.P., and Anderson, R.B. (eds) 2007 International Handbook of Research on Indigenous Entrepreneurship, Cheltenham, UK \& Massachusetts, USA.: Edward Elgar.

Duncan, R. 2008 'Cultural and economic tensions in Pacific Islands' futures', International Journal of Social Economics, 35, (12): 919-929.

Durutalo, A. 1997 Provincialism and the Crisis of Indigenous Fijian Political Unity. Unpublished MA Thesis, School of Social and Economic Development, The University of the South Pacific, Fiji.

Durkheim, E. 1897 Le Suicide: Étude de Sociologie, Paris: Félix Alcan.

Fairbairn, T.I.J. 1988 'Indigenous entrepreneurship and business development in the Cook Islands., in Island entrepreneurs: Problems and performance in the South Pacific. Honolulu: East-West Centre Pacific Islands Development Program:55- 76.

Farrelly, T. 2009 Business Va'avanua: Cultural Hybridisation and Indigenous Entrepreneurship in the Bouma National Heritage Park, PhD Thesis, Anthropology Programme, Massey University, Palmerston North, New Zealand.

Farrelly, T. 2011 'Indigenous and democratic decision-making: issues from community-based ecotourism in the Boumā National Heritage Park, Fiji, Journal of Sustainable Tourism, 19 (7):817-835.

Farrelly, T. 2013 'Community-based ecotourism as indigenous social entrepreneurship', in Holden, A. and D. Fennel (eds) The Routledge Handbook of Tourism and Environment. Routledge, London: 447-459.

Fijian Affairs Act (Cap 120, 1945 [Revised2006]). Retrieved from http://www. itaukeiaffairs.gov.fj/docs/Fijian\%2oAffairs\%2oAct\%20CAP120\%2oRev\%2O 2006.pdf

Firth, R. 1929 Primitive Economics of the New Zealand Maori. London: Routledge. 
Geschiere, P. 2001 'Money versus kinship: subversion or consolidation?', The Asia Pacific Journal of Anthropology, 1 (1):54-78.

Gibson-Graham, J.K. 1996 The End of Capitalism (As We Knew It): A Feminist Critique of Political Economy. Oxford: Blackwell.

Gibson-Graham, J.K. 2006 A Postcapitalist Politics, Minneapolis \& London: University of Minnesota Press.

Gregory, C.A. 1982 Gifts and Commodities. London: Academic Press.

Gudeman, S. 1986 Economics as Culture: Models and Metaphors of Livelihood. London: Routledge \& Kegan Paul.

Gudeman, S. 2009 'Necessity or contingency: Mutuality and market', in Hann, C.M. \& Hart. K (eds) Market and Society: The Great Transformation Today: Cambridge: Cambridge University Press: $17-37$.

Guijt, I. M., \& Shah, M.K. 1999 The Myth of Community: Gender Issues in Participatory Development. New Delhi: Sage.

Hann, C. \& K. Hart, eds. 2009 Market and Society: The Great Transformation Today. Cambridge: Cambridge University Press.

Hann, C. and Hart, K. 2011 Economic Anthropology. Cambridge: Polity.

Hart, K. 2010 'Informal economy', in K. Hart, K.J.L. Laville, and A.D. Cattani (eds). The Human Economy: A Citizen's Guide, Cambridge: Polity Press:142-155.

Hart, K., \& Hann, C. 2009. 'Introduction: learning from Polanyi', in C. Hann, \& K. Hart (eds.), Market and society: The Great Transformation Today. Cambridge: CambridgeUniversity Press:1-16.

Harrington, C. 2004 'Marriage' to capital: the fallback positions of Fiji s women garment workers', Development in Practice, 14(4):495-507.

Hindle, K. and Lansdowne, M. 2007 'Brave spirits on new paths: globally relevant paradigm of indigenous entrepreneurship research', in L.P. Dana \& R.B. Anderson (eds) International Handbook of Research on Indigenous Entrepreneurship, Cheltenham, UK: Edward Elgar Publishing: 8-19. 
Hobsbawm, E., and Ranger, T. (eds) 1983 The Invention of Tradition, Cambridge University Press, New York.

Hobsbawm, E. 1983 'Inventing traditions', in E.H.T. Ranger (ed) The Invention of Tradition. New York: Cambridge University Press:1-14.

Ingram, P. T. 1990 Indigenous Entrepreneurship and Tourism Development in the Cook Islands and Fiji, PhD Thesis, Massey University, Palmerston North, New Zealand.

Jolly, M. 1992 'Spectres of inauthenticity', Contemporary Pacific, 4:49-72.

Keesing, R. 1982 'Kastom and anticolonialism on Malaita: "culture” as political symbol', Mankind, 13(4):357-373.

Larmour, P. (ed) 1997 The Governance of Common Property in the Pacific Region. Canberra: National Centre for Development Studies

Larmour, P. 2008 Guarding the Guardians: Accountability and Anticorruption in Fijis Cleanup Campaign, Honolulu: East-West Centre.

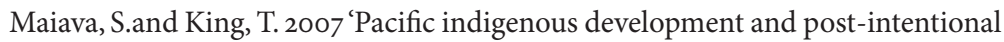
realities', in A. Ziai (ed) Exploring Post-Development: Theory and Practice, Problems and Perspectives, London \& New York: Routledge: 83-98.

Mauss, M. 1925 The Gift (trans. I. Cunnison). London: Cohen and West.

McClelland, D.C. (ed) 1961 The Achieving Society, New York: Van Nostrand.

McCormack, F. and Barclay, K. (eds) 2013 Engaging with Capitalism: Cases from Oceania. Bingley: Emerald Group Publishing.

Nabobo-Baba, U. 2006 Knowing and learning: An Indigenous Fijian Approach. University of the South Pacific: Fiji.

Narayan, J. (ed) 1984 The Political Economy of Fiji, Suva, Fiji: South Pacific Review Press.

Nayacakalou, R.R. (ed) 1978 Tradition and Change in the Fijian Village, South Pacific Social Sciences Association and the Institute of Pacific Studies, Suva: University of the South Pacific. 
Novaczek, I., Mitchell, J., and Veitayaki, J. (eds) 2005 Pacific Voices: Equity and Sustainability in Pacific Islands Fisheries, Institute of Pacific Studies, Suva, Fiji: University of the South Pacific.

Oliver, Dennis 1983 Trickling Up: A Strategy for Development where the People at the Bottom Matter Most. Suva, Fiji: Lotu Pasifika Productions.

Peredo, A., Anderson, R., Galbraith, C., \& Honig, B. 2004 'Towards a theory of indigenous entrepreneurship', International Journal of Entrepreneurship and Small Business, 1(1):1-20.

Polanyi, K. 1944 The Great Transformation: The Political and Economic Origins of Our Time, New York: Farrar \& Rinehart.

Popkin, S.L. 1979 The Rational Peasant: The Political Economy of Rural Society in Vietnam. California: University of California Press.

Prasad, S. 2007 'Perpetual kerekere will only entrench dependency on aid', Fiji Times Online, Retrieved from http://www.fijitimes.com/story.aspx?id=61981,

Rao, D.R. 2004 Culture and Entrepreneurship in Fijis Small Tourism Business Sector, $\mathrm{PhD}$ Thesis, Victoria University, Australia.

Ratuva, S. 2002 'Anatomizing the vanua concept: Intra-communal land disputes and implications on the Fijian community', Conference on South Pacific Land Tenure Conflict Symposium, University of the South Pacific, Suva.

Ravuvu, A. 1976. 'Religious beliefs', in S. Vatu (ed) Na Veitalanoa me Baleta na $i$ Tukutuku Maroroi: Talking About Oral Traditions, Suva: Fiji Museum: 45-47.

Ravuvu, A. (ed) 1983 Vaka $i$ Taukei: The Fijian Way of Life, Suva, Fiji: University of the South Pacific.

Ravuvu, A. 1987 'Fiji: contradictory ideologies and development', in A. Hooper et al. (eds) Class and Culture in the South Pacific,. Suva, Fiji: Institute of Pacific Studies.

Ravuvu, A. 1988 Development or Dependence: The Pattern of Change in a Fijian Village. Suva, Fiji: University of the South Pacific.Ravuvu, A. 20oo. The Facade of Democracy. Retrieved from http://www.scoop.co.nz/stories/WOooo6/ Soo11o.htm 
Sahlins, M. (ed) 1962 Moala, Ann Arbor, US: University of Michegan Press.

Sahlins, M. 1972 Stone Age Economics, Chicago: Aldine-Atherton.

Sahlins, M. 1993 'Cery cery fuckabede', American Ethnologist, 20(4): 848-867.

Sahlins, Marshall 2013 The Culture of Material Value and the Cosmography of Difference. Lecture give at Kings College, University of Cambridge, July 2013. Retrieved from http://www.youtube.com/watch?v=13vX9VbPbkA.

Sayer, A. 2000 'Moral economy and political economy', Studies in Political Economy, 61:79-103.

Schneider, H.K. 1974 Economic Man. New York: Free Press.

Scott, J.C. 1976 The Moral Economy of the Peasant: Rebellion and Subsistence in Southeast Asia, New Haven, Connecticut: Yale University Press.

Scott, J.C. 1985 Weapons of the Weak: Everyday Forms of Peasant Resistance, New Haven: Yale University Press.

Spate, O.H.K. 1959 The Fijian People: Economic Problems and Prospects: A Report, Legislative Council Paper no. 13, Government Printer, Suva, Fiji: Government Press.

Stolz, E. (2012) 'Na Hina Shines', Retrieved from http://www.fijisun.comf// 2012/o9/13/na-hina-shines/

Tears For Fiji 2010 Villagers Urged to Get Rid of Kerekere, Retrieved from http:// tearsforfiji.blogspot.co.nz/2010_04_01_archive.html

Thomas, N. 1989 Out of Time: History and Evolution in Anthropological Discourse, Cambridge: Cambridge University Press.

Thomas, N. 1992 'The inversion of tradition', American Ethnologist, 19 (2):213-232.

Thomas, N. (1992a) 'Substantivization and anthropological discourse: The transformation of practices into institutions in neotraditional Pacific societies', in J.G. Carrier (ed) History and Tradition in Melanesian Anthropology, Berkeley, CA: University of California Press: 64-85. 
Thomas, N. 1993 'Beggars can be choosers', American Ethnologist, 20 (4):868-876.

Thompson, E.P. 1971 The moral economy of the English crowd in the 18th century', Past \& Present, 50:76-136.

Turnbull, J. 2003 'South Pacific agendas in the quest to protect natural areas', Development and Change, 34(1):1-24.

Tuwere, I.S. (ed) 2002 Vanua: Towards a Fijian Theology of Place, Suva, Fiji: University of the South Pacific.

Veitayaki, J. 2002 'Taking advantage of indigenous knowledge: the Fiji case', International Social Science Journal, 54, (173):395-402.

Wertheim, W. 1965 (ed) East-West Parallels: Sociological Approaches to Modern Asia. Chicago: Quadrangle Books.

Wilk, R. and Cliggett L. 1996 Economies and Cultures. (2nd ed), Boulder CO: Westview.

Williksen-Bakker, S. 2002 'Fijian business-a bone of contention: was it one of the factors leading to the political crisis of 2000? The Australian Journal of Anthropology, 13:72-87.

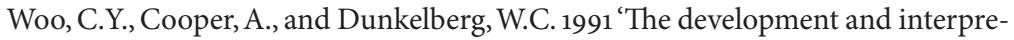
tation of entrepreneurial typologies', Journal of Business Venturing, 6:94-114.

Yari, M. 2003 'Beyond "subsistence affluence": poverty in Pacific Island countries', in United Nations Bulletin on Asia-Pacific Perspectives 2003/04, Asia-Pacific Economies, Maintaining Dynamism, un/Escap Bangkok: 41-53. 